\title{
Analisa Aliran Daya Pada Sistem Tenaga Listrik Dengan Metode Fast Decoupled Menggunakan Software Etap
}

\author{
Arnawan Hasibuan ${ }^{1,2}$, Muzamir Isa ${ }^{1}$, Mohd Irwan Yusoff ${ }^{2}$, Siti Rafidah Abdul Rahim ${ }^{2}$ \\ ${ }^{1}$ Fakultas Teknik Manajemen, Fakultas Ekonomi dan Bisnis, \\ Universitas Malikussaleh \\ Jl. Cot Tengku Nie, Reuleut, Muara Batu, Aceh Utara, Indonesia Telp. + (62) 645.41373 \\ ${ }^{2}$ School of Electrical System Engineering, \\ Universiti Malaysia Perlis, Malaysia \\ 02600 Arau, Perlis, Malaysia Phone: +60 4-988 5601 \\ e-mail: arnawan@unimal.ac.id
}

\begin{abstract}
Abstrak - Untuk menunjang bertambahnya permintaan energi listrik harus diimbangi dengan peningkatan kualitas energi listrik yang disalurkan. Dengan melakukan suatu analisa terhadap sistem tenaga merupakan salah satu cara untuk meningkatkan kualitas energi listrik, dikarenakan analisa sistem tenaga mencakup beberapa permasalahan utama dalam sistem tenaga. Salah satunya yaitu aliran daya, studi aliran daya dilakukan untuk mendapatkan informasi mengenai aliran daya dan tegangan sistem dalam kondisi operasi tunak.. Untuk menyelesaikan aliran daya, penulis menggunakan software ETAP 12.6 untuk mensimulasikan aliran daya pada 37 bus sistem standar IEEE. Adapun metode aliran daya yang digunakan adalah metode Fast Decoupled, maka dapat diketahui aliran daya, daya aktif sebesar 2.338.000 Watt, daya reaktif sebesar 7.771.000 Var, dan. Total drop tegangan pada jaringan $220 \mathrm{kV}$ sebesar $31.9 \%$, nilai losses yang diperoleh dari keseluruhan sistem, untuk daya aktif (P) yaitu sebesar 766.200 Watt, daya reaktif (Q) yaitu sebesar 3.557.200 Var. Bus yang digunakan untuk simulasi ini sebanyak 37 bus, diantaranya 1 untuk bus GH (swing bus)dan sumber daya (Power Grid) diamsusikan sebesar 6.667 Mvasc, 220kV dengan Frekuensi $50 \mathrm{~Hz}$, jaringan yang digunakan yaitu sistem radial.
\end{abstract}

\begin{abstract}
Kata kunci : Aliran Beban, Etap, Fast Decouple
Abstract - To support the increasing demand for electrical energy, it must be balanced with an increase in the quality of electrical energy supplied. By conducting an analysis of the power system is one way to improve the quality of electrical energy, because the power system analysis covers several major problems in the power system. One of them is power flow. A power flow study is conducted to obtain information about the power flow and system voltage under steady operating conditions. To solve the power flow, the authors use ETAP 12.6 software to simulate power flow on 37 buses of the IEEE standard system. The power flow method used is the Fast Decoupled method, it can be seen that the power flow, active power is 2,338,000 Watts, reactive power is 7,771,000 Var, and. The total voltage drop on the 220 $\mathrm{kV}$ network is $31.9 \%$, the value of losses obtained from the whole system, for active power $(P)$ is 766,200 Watts, reactive power $(Q)$ is 3,557,200 Var. There are 37 buses used for this simulation, including 1 for the GH (swing bus) and power grid (Power Grid) buses which are used for 6,667 Mvasc, 220kV with a frequency of $50 \mathrm{~Hz}$, the network used is a radial system.
\end{abstract}

Keywords : $\quad$ Power Flow, Etap, Fast Decouple

\section{PENDAHULUAN}

Untuk menunjang bertambahnya permintaan energi listrik harus diimbangi dengan peningkatan kualitas energi listrik yang disalurkan. Dengan melakukan suatu analisa terhadap sistem tenaga merupakan salah satu cara untuk meningkatkan kualitas energi listrik, dikarenakan analisa sistem tenaga mencakup beberapa permasalahan utama dalam sistem tenaga yaitu aliran beban, hubung singkat, stabilitas dan pengaman. Keempat masalah tersebut adalah faktor penting untuk meningkatkan kualitas energi listrik yang disalurkan [1].
Studi aliran daya ialah analisis yang digunakan untuk menentukan dan menghitung tegangan, arus, daya, dan faktor daya atau daya reaktif yang terdapat pada berbagi titik dalam suatu jaringan listrik pada keadaan pengoperasian normal, baik yang sedang berjalan maupun yang diharapkan akan terjadi di masa yang akan datang. Analisa aliran daya sangat penting dalam perencanaan pengembangan suatu sistem tersebut banyak tergantung pada efek interkoneksi dengan sistem tenaga yang lain, beban yang baru, stasiun pembangkit baru, serta saluran transmisi baru, sebelum semuanya dipasang [2] [3]. Dengan studi semacam ini akan menjamin bahwa 
sistem tenaga yang baru dapat memenuhi kebutuhan listrik secara ekonomis, efesien dan aman.

Untuk mendapatkan hasil yang diinginkan dalam studi aliran daya pada sistem tenaga listrik ini dikenal beberapa metode, antara lain metode Gauss Seidel, metode Newton Raphson dan metode Fast Decouple. Dalam paper ini akan dipaparkan aliran daya pada 37 bus pada sistem standard IEEE menggunakan metode Fast Decouple dengan software Etap 12.6.0.

Tujuan dari penulisan paper ini adalah untuk memperkenalkan studi aliran daya dengan metode Fast Decouple dan mengimplementasikan metode Fast Decouple ini dalam suatu perangkat lunak (software) yang diaplikasikan pada sistem tenaga listrik.

\section{TINJAUAN PUSTAKA}

\section{A. 2.1 Aliran Daya}

Studi aliran daya atau load flow study adalah suatu studi yang mempelajari aliran daya pada suatu sistem kelistrikan dari suatu titik ke titik lain dan tegangan pada bus-bus yang berada pada sistem tersebut. Studi aliran daya merupakan penentuan atau perhitungan tegangan, arus, daya aktif, faktor daya dan daya reaktif yang terdapat pada berbagai titik dalam suatu jaringan sistem tenaga listrik pada keadaan pengoperasian normal, baik yang sedang berjalan maupun yang diharapkan akan terjadi di masa yang akan datang [4]. Studi analisis aliran daya dapat dihitung secara manual maupun menggunakan software computer.

Tujuan dari studi aliran daya, yaitu:

a. Untuk mengetahui komponen jaringan sistem tenaga listrik pada umumnya.

b. Mengetahui besarnya tegangan pada setiap bus (rel) dari suatu sistem tenaga listrik.

c. Menghitung aliran-aliran daya, baik daya nyata maupun daya reaktif yang mengalir dalam setiap saluran.

d. Kerugian-kerugian sistem yang optimal.

e. Perbaikan dan pergantian ukuran konduktor dan tegangan sistem.

Perhitungan aliran daya merupakan suatu alat bantu yang sangat penting untuk mengetahui kondisi operasi sistem. Perhitungan aliran daya pada tegangan, arus dan faktor daya di berbagai simpul suatu jaringan listrik dilakukan pada keadaan operasi normal. Hasil perhitungan aliran daya ini kemudian digunakan untuk mensimulasi kondisi gangguan yang besar, stabilitas transien maupun analisa kontigensi yaitu analisa keadaan dimana sebagian komponen sistem tidak terhubung ke sistem dengan baik.

Perhitungan aliran daya membutuhkan informasi ramalan kebutuhan bebas di setiap titik pelayanan, rencana operasi pusat pembangkit dan rencana operasi fasilitas tranmisi. Dan informasi diatas dapat disusun persamaan aliran daya dari satu Gardu Induk ke Gardu Induk lainnya.

Aliran daya adalah studi yang dilaksakan untuk mendapatkan informasi mengenai aliran daya atau tegangan sistem dalam kondisi operasi lunak. Informasi ini sangat dibutuhkan guna mengevaluasi unjuk kerja sistem tenaga dan menganalisa kondisi pembangkitan maupun pembebanan. Analisis ini memerlukan pula informasi aliran dalam kondisi normal maupun darurat.

Masalah aliran daya mencakup perhitungan aliran dan tegangan sistem pada terminal tertentu. Representasi tunggal selalu dilakukan karena sistem di anggap seimbang.

Tujuan aliran daya adalah untuk mengetahui besar vektor tegangan pada tiap bus dan besar aliran daya pada tiap cabang suatu jaringan untuk suatu kondisi beban tertentu dalam kondisi normal. Hasil perhitungan dapat digunakan untuk menelaah berbagai persoalan yang berhubungan dengan jaringan tersebut, yaitu meliputi hal - hal yang berhubungan dengan operasi jaringan yaitu :

1. Pengaturan tegangan (voltage regulation), perbaikan faktor daya (power factor) jaringan, kapasitas kawat penghantar, termasuk rugi - rugi daya.

2. Perluasan atau pengembangan jaringan, yaitu menentukan lokasi yang tepat untuk penambahan bus beban baru dan unit pembangkitan atau gardu induk baru.

3. Perencanaan jaringan, yaitu kondisi jaringan yang diinginkan pada masa mendatang untuk melayani pertumbuhan beban karena kenaikan terhadap kebutuhan tenaga listrik.

Dalam Studi Aliran Daya dikenal berbagai Bus, yaitu [5] :

1. Bus referensi (slack bus atau swing bus)

Slack bus berfungsi untuk mencatu rugirugi dan kekurangan daya aktif dan reaktif pada jaringan. Karena itu bus yang biasa digunakan adalah bus yang berdaya besar, dimana tegangan dan sudut fasanya diketahui.

a. Terhubung dengan generator.

b. V dan sudut fasa dari generator diketahui dan tetap.

c. $\mathrm{P}$ dan $\mathrm{Q}$ dihitung.

2. Generator bus (bus pembangkitan) atau (P$\mathrm{V}$ bus)

Generator bus atau Voltage Generator bus berfungsi tidak hanya untuk pengontrol tegangan akan tetapi juga dapat menambah 
daya dalam sistem karena bus ini paling kurang terkoneksi dengan 1 buah generator.

a. Terhubung dengan generator.

b. $\mathrm{P}$ dan $\mathrm{V}$ dari generator diketahui dan tetap

c. Sudut fasa dan $\mathrm{Q}$ dari daya reaktif generator dihitung.

3. Bus pembebanan (P-Q bus)

Bus pembebanan atau yang biasa juga disebut sebagai Load bus adalah bus beban yang memiliki besaran nilai daya aktif $(\mathrm{P})$ dan daya reaktif (Q) yang diketahui. Pada bus ini tidak ada generator yang terkoneksi melainkan hanya terkoneksi dengan beban saja.

a. Terhubung dengan generator.

b. $\mathrm{P}$ dan $\mathrm{V}$ dari generator diketahui dan tetap

c. V dan sudut fasa tegangan di hitung.

\subsection{Konsep Perhitungan Aliran Daya}

Perhitnugan aliran daya pada dasarnya adalah menghitung besaran tegangan $|\mathrm{V}|$ dan susdut fasa tegangan $\delta$ pada setiap G.I pada kondisi tunak dan kondisi fasa tidak seimbang. Hasil perhitungan ini digunakan untuk menghitung besar aliran daya aktif $\mathrm{P}$ dan daya reaktif $Q$ di setiap peralatan transmisi, besaran daya aktif $\mathrm{P}$ dan daya reaktif $\mathrm{Q}$ yang harus dibangkitkan disetiap pusat pembangkitan serta jumlah rugi-rugi di sistem.

Pada setiap bus ada 4 variable operasi yang terkait, yaitu daya aktif $\mathrm{P}$, reaktif $\mathrm{Q}$, besaran tegangan $|\mathrm{V}|$ dan sudut fasa tegangan $\delta$. Agar persamaan aliran daya dapat dihitung, 2 dari 4 variable di atas harus diketahui untuk setiap bus, sedangkan 2 variable lainnya dihitung.

\subsection{Persamaan Aliran Daya}

Sistem tenaga listrik tidak hanya terdiri dari dua bus, melainkan terdiri dari beberapa bus yang akan diinterkoneksi satu sama lain [6]. Daya listrik yang diinjeksikan oleh generator kepada salah satu bus, bukan hanya dapat diserap oleh beban bus tersebut, melainkan dapat juga diserap oleh beban dibus yang lain. Kelebihan daya pada bus akan dikirimkan melalui saluran tranmisi ke bus-bus yang lain yang kekurangan daya.

Diagram satu garis tipe bus dari suatu sistem tenaga listrik terdapat pada Gambar 1.

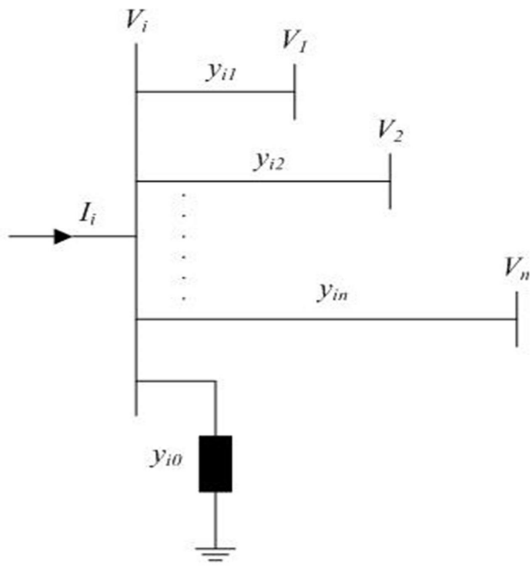

Gambar 1. Diagram satu garis tipe bus dari sistem tenaga listrik.

Arus pada bus ke i [7] adalah :

$I_{i}=V_{i} \sum_{j=0}^{n} y_{i j} \sum_{j=i}^{n} y_{i j} V_{j}$ dimana $\mathrm{j} \neq \mathrm{i} \ldots . .(1)$

Persamaan daya pada bus ke i adalah :

$P_{i}+j Q_{i}=V_{i} I_{i}{ }^{*}$

Atau

$I_{i}=\frac{P i-j}{V i *}$

Dengan mensubtitusikan persamaan (3) ke persamaan (1) diperoleh :

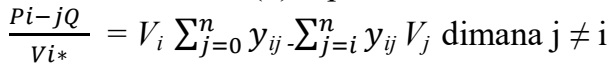

\subsection{Rugi-rugi Daya Pada Saluran}

Rugi-rugi daya pada saluran dapat direpresentasikan berdasarkan Gambar 2.

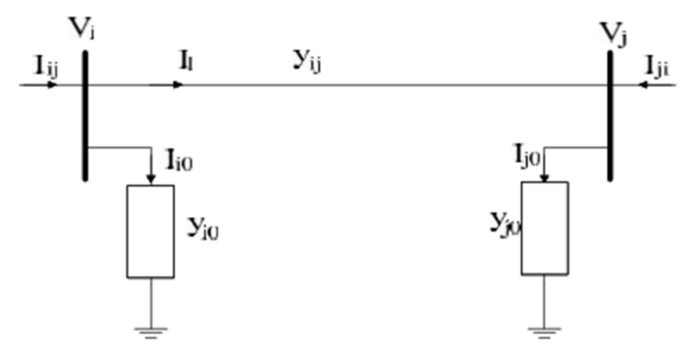

Gambar 2. Diagram representasi rugi-rugi daya

Dari Gambar 2 di atas dapat dinyatakan bahwa arus yang mengalir dari $\mathrm{i}$ ke $\mathrm{j}$ adalah:

$I_{i}=I_{l}+I_{i 0}=y_{i,}\left(V_{i}-V_{j}\right)+y_{i 0} V_{j}$

Begitu pula sebaliknya, arus yang mengalir dari $\mathrm{j}$ ke i dapat dinyatakan dengan:

$I_{j:}=-I_{l}+I_{j 0}=y_{i,}\left(V_{j}-V_{i}\right)+y_{j 0} V_{j}$ 
Daya semu $S_{i}$ dari bus i ke j dan dari $S_{j}$ bus j ke i yang terjadi pada konduktor adalah:

$\mathrm{S}_{\mathrm{i}}=\mathrm{V}_{\mathrm{i}} \mathrm{I}_{\mathrm{I}}$

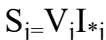

Rugi - rugi daya yang terjadi dari i ke j secara aljabar dapat ditulis sebagai berikut:

$\mathrm{S}_{\mathrm{Li}}=\mathrm{S}_{\mathrm{i}}+\mathrm{S}_{\mathrm{j}}$

Dengan begitu, untuk menghitung nilai rugirugi secara keseluruhan dari jaringan dapat dihitung dengan menjumlahkan seluruh rugi-rugi yang diperoleh pada setiap saluran.

$$
S_{L}=\sum_{\substack{i=1 \\ j=i+1}}^{n} S_{i} \quad ;(\mathrm{i} \neq \mathrm{j}) \ldots
$$

\subsection{Susut Tegangan}

Apabila melalui saluran listrik (hantaran udara atau kabel tanah) disalurkan arus listrik, maka akan di alami susut tegangan pada saluran akibat adanya impedansi saluran. Susut tegangan ini perlu dihitung untuk menjamin bahwa tegangan pelayanan dikonsumen terujung tidak dibawah batas minimum yang di ijinkan.

Tegangan adalah suatu besaran listrik yang dipasok dari pembangkit tenaga listrik ke beban melalui gardu induk atau gardu distribusi, perlu mendapat perhatian dan pemasok tenaga listrik, karena peralatan - peralatan listrik yang dipakai pelanggan telah didesain oleh pabrik pembuatnya, sesuai dengan sistem tegangan yang telah distandarkan oleh suatu negara. Penurunan tegangan atau kenaikan tegangan sangat berpengaruh pada peralatan - peralatan listrik, yang dapat memanaskan bahkan dapat merusak peralatan listrik tersebut. Jika tegangan yang dipasok ke beban turun dibawah tegangan nominalnya, dapat berpengaruh pada peralatan listrik, jadi kestabilan tegangan yang dipasok dan pemasok tenaga listrik, harus dipertahankan. Sesuai SNI tahun 2000, bahwa kenaikan tegangan di Indonesia yang di ijinkan $+5 \%$ dan penurunan tegangan yang di ijinkan $-10 \%$. Artinya jika tegangan 220 Volt kenaikan tegangan sebesar $(220+5 \% \times 220)$ Volt 231 Volt dan turunnya tegangan yang di ijinkan $(220-10 \% \times 220)$ Volt 198 Volt. [8].

Aliran Daya dengan Metode Fast Decoupled

Bentuk matrik jacobian untuk aliran daya $V_{\text {imin }} \leq$ $\mathrm{V}_{\mathrm{i}} \leq \mathrm{V}_{\text {imax }}$ metode decouple [9] :

$$
\left[\begin{array}{l}
\Delta \mathrm{P} \\
\Delta \mathrm{Q}
\end{array}\right]=\left[\begin{array}{cc}
\mathrm{H} & 0 \\
0 & \mathrm{~L}
\end{array}\right]\left[\begin{array}{c}
\Delta \delta \\
\frac{\Delta|\mathrm{V}|}{\mathrm{V}}
\end{array}\right] .
$$

Dari matrik diatas didapat dua persamaan berikut :

$$
[\Delta \mathrm{P}]=[\mathrm{H}][\Delta \delta]
$$

Dan

$$
[\Delta \mathrm{Q}]=[\mathrm{L}]\left[\frac{[\Delta \mathrm{V}]}{\mathrm{V}}\right]
$$

Dengan elemen dari jacobian untuk $\mathrm{H}$ dan $\mathrm{L}$ adalah :

$$
\begin{aligned}
& \mathrm{H}_{\mathrm{ij}}=\mathrm{L}_{\mathrm{ij}}=\frac{\delta p \mathrm{i}}{\delta \delta j}=\mid \mathrm{V}_{\mathrm{i}} \mathrm{V}_{\mathrm{j}}[G i j \sin [\delta i-\delta j]-B i j \operatorname{Cos}[\delta i-\delta j]] \\
& \mathrm{H}_{\mathrm{ii}}=\frac{\delta P i}{\delta \delta j}=-\sum_{\substack{j=1 \\
j \neq i}}^{n}|\operatorname{ViVjYij}| \sin [\theta i j+\delta i-\delta j] \\
& =-\mathrm{V}_{\mathrm{i}}^{2} \mathrm{~B}_{\mathrm{ii}}-\mathrm{Q}_{\mathrm{i}}
\end{aligned}
$$

$$
\begin{array}{r}
\mathrm{L}_{\mathrm{in}}=\frac{\delta Q i|V i|}{\delta V i}=|2 \mathrm{Vi} 2 \mathrm{Yii}| \sin \theta \mathrm{ii}+\sum_{\substack{j=1 \\
j \neq i}}^{n} \mid \sin [\theta \mathrm{ij}+\delta \mathrm{i}-\delta \mathrm{j}] \\
=\mathrm{V}_{\mathrm{i}}{ }^{2} \mathrm{~B}_{\mathrm{ii}}+\mathrm{Q}_{\mathrm{i}} \ldots \ldots \ldots \ldots \ldots \ldots \ldots \ldots \ldots \ldots \ldots \ldots \ldots \ldots \ldots \ldots \ldots \ldots
\end{array}
$$

\section{1) 2.6. Fungsi Obyektif}

Fungsi objektif dari aliran daya optimal pada generator guna meminimisasi biaya dengan persamaan biaya dari daya yang dihasilkan generetor

$$
\mathrm{C}_{\mathrm{pgi}}=\mathrm{a}_{\mathrm{i}}+\mathrm{b}_{\mathrm{i}} \mathrm{P}_{\mathrm{gi}}+\mathrm{C}_{\mathrm{i}} \mathrm{P}_{\mathrm{gi}}{ }^{2} .
$$

Dimana $\mathrm{P}_{\mathrm{gi}}$ merupakan daya keluaran pada generator ke i, sehingga fungsi objek adalah penjumlahan biaya dari masing-masing generator yang dapat ditulis sebagai berikut :

$$
\mathrm{F}(\mathrm{x})=\sum_{i}(a i+b i P G i+C i P g i 2) \ldots
$$

\section{2) Persamaan Kekangan}

Persamaan aliran daya Grainger dan stevenson dengan daya aktif dan reaktif pada masing-masing bus:

$$
\begin{gathered}
\frac{\partial p}{\partial \delta j}=0=-|V i V j|\{B i j \cos (\delta j-\delta i)+G i j \sin (\delta j- \\
\delta i)\}-P g i+P d i \ldots \ldots \ldots . .(18) \\
|\mathrm{V}| \frac{\partial Q i}{\partial|V j|}=0=-|V i V j|\{B i j \operatorname{Cos}(\delta j-\delta i)- \\
\operatorname{Gij} \sin (\delta j-\delta i)\}-Q g i+Q d i \ldots \ldots \ldots \ldots . .(19)
\end{gathered}
$$

Dengan persamaan kekangan tegangan :

$$
\mathrm{V}_{\mathrm{Gi}} \mathrm{V}_{\mathrm{Gi}} \mathrm{set}=0 .
$$

Pertidaksamaan Kekangan

Daya maksimum dan minimum generator ke bus i :

$$
\begin{aligned}
& \mathrm{P}_{\text {gimin }} \leq \mathrm{P}_{\text {gi }} \leq \mathrm{P}_{\text {gimaks }} \\
& \mathrm{Q}_{\text {gimin }} \leq \mathrm{Q}_{\text {gi }} \leq \mathrm{Q}_{\text {gimaks }}
\end{aligned}
$$

Perbandingan tap maksimum dan minimum dari perubahan tap transformator yang diinginkan dan perubahan phasa transformator mempunyai nilai maksimum dan minimum dengan pertidaksamaan kekangan :

$$
\begin{aligned}
\mathrm{t}_{\mathrm{kmmin}} & \leq \mathrm{t}_{\mathrm{km}} \leq \mathrm{t}_{\mathrm{kmmax}} \\
\alpha_{\mathrm{kmmin}} & \leq \alpha_{\mathrm{km}} \leq \alpha_{\mathrm{kmmax}}
\end{aligned}
$$

Guna mempertahan kualitas pelayanan listrik dan keamanan sistem. Tegangan bus mempunyai besaran maksimum. Batas dari pertidaksamaan kekangan adalah :

$\mathrm{V}_{\text {imin }} \leq \mathrm{V}_{\mathrm{i}} \leq \mathrm{V}_{\text {imax }}$ 


\section{METODE}

Penelitian ini dilakukan di Laboratorium Teknik Elektro Universitas Malikussaleh dengan objek yang diuji adalah sistem standar IEEE 37 bus yang selanjutnya disimulasi dengan software ETAP.

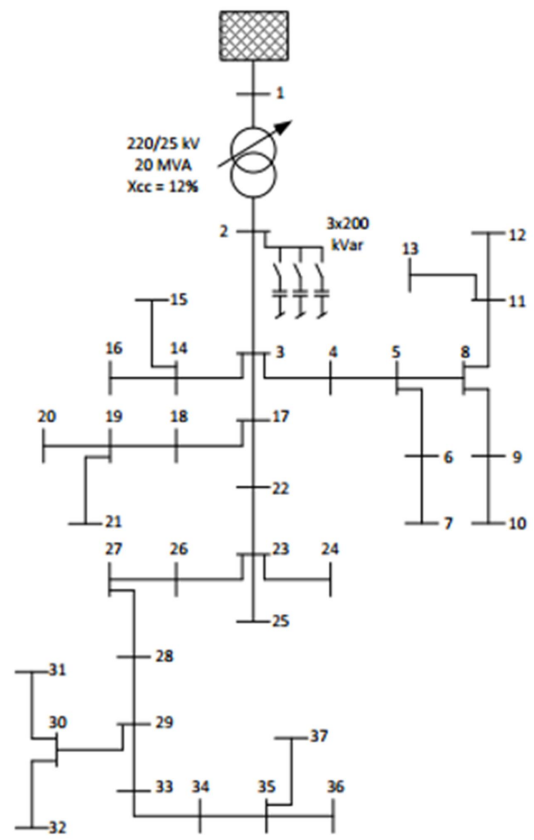

Gambar 2. Konfigurasi jaringan IEEE 37 bus

\section{A. Teknik Pengumpulan Data}

Teknik pengumpulan data adalah lapangan. Cara ini penulis lakukan dengan mengumpulkan data data yang ada pada standar IEEE sistem jaringan 37 bus yaitu sebagai berikut :

Tabel 1. Data Input Beban

\begin{tabular}{|c|c|c|c|c|c|c|c|}
\hline \multirow{2}{*}{$\begin{array}{c}\text { Nomo } \\
\text { r Bus }\end{array}$} & $\begin{array}{c}\text { Teganga } \\
\mathrm{n}(\mathrm{kV})\end{array}$ & \begin{tabular}{c} 
Generator \\
\cline { 3 - 7 }
\end{tabular} & $\begin{array}{c}\mathrm{P}(\mathrm{kW} \\
\text { Q(kVar }\end{array}$ & $\begin{array}{c}\mathrm{P}(\mathrm{kW} \\
)\end{array}$ & $\begin{array}{c}\text { Q(kVar } \\
)\end{array}$ & $\begin{array}{c}\text { Facto } \\
\mathrm{r}\end{array}$ & $\begin{array}{c}\text { Tip } \\
\mathrm{B}\end{array}$ \\
\hline 1 & 220 & - & - & 0 & 0 & 1 & 2 \\
\hline 2 & 25 & 0 & 0 & 0 & 0 & 1 & 3 \\
\hline 3 & 25 & 0 & 0 & 146 & 66 & 0,91 & 0 \\
\hline 4 & 25 & 0 & 0 & 116 & 56 & $\begin{array}{c}21.3 \\
6\end{array}$ & 0 \\
\hline 5 & 25 & 0 & 0 & 146 & 70 & 0,9 & 0 \\
\hline 6 & 25 & 0 & 0 & 87 & 42 & 0,9 & 0 \\
\hline 7 & 25 & 0 & 0 & 194 & 99 & 0,89 & 0 \\
\hline 8 & 25 & 0 & 0 & 340 & 164 & 0,9 & 0 \\
\hline 9 & 25 & 0 & 0 & 456 & 221 & 0,9 & 0 \\
\hline 10 & 25 & 0 & 0 & 349 & 169 & 0,9 & 0 \\
\hline 11 & 25 & 0 & 0 & 514 & 234 & 0,91 & 0 \\
\hline
\end{tabular}

\begin{tabular}{|c|c|c|c|c|c|c|c|}
\hline \multirow{2}{*}{$\begin{array}{l}\text { Nomo } \\
\mathrm{r} \text { Bus }\end{array}$} & \multirow{2}{*}{$\begin{array}{l}\text { Teganga } \\
\mathrm{n}(\mathrm{kV})\end{array}$} & \multicolumn{2}{|c|}{ Generator } & \multicolumn{2}{|c|}{ Beban } & \multirow{2}{*}{\begin{tabular}{|c|} 
Powe \\
$r$ \\
Facto \\
$r$
\end{tabular}} & \multirow{2}{*}{\begin{tabular}{|c} 
Tip \\
e \\
Bus
\end{tabular}} \\
\hline & & $\begin{array}{c}\mathrm{P}(\mathrm{kW} \\
)\end{array}$ & $\begin{array}{c}\mathrm{Q}(\mathrm{kVar} \\
)\end{array}$ & $\begin{array}{c}\mathrm{P}(\mathrm{kW} \\
)\end{array}$ & $\begin{array}{c}\mathrm{Q}(\mathrm{kVar} \\
)\end{array}$ & & \\
\hline 12 & 25 & 0 & 0 & 437 & 224 & 0,89 & \\
\hline 13 & 25 & 0 & 0 & 679 & 329 & 0,9 & \\
\hline 14 & 25 & 0 & 0 & 349 & 169 & 0,9 & \\
\hline 15 & 25 & & & 01 & 308 & 0,89 & \\
\hline 16 & 25 & 0 & 0 & 349 & 169 & 0,9 & \\
\hline 17 & 25 & c & 0 & 912 & 442 & 0,9 & \\
\hline 18 & 2 & 0 & 0 & 349 & 159 & 0,91 & \\
\hline 19 & 25 & 0 & 0 & 485 & 235 & 0,9 & \\
\hline 20 & 25 & 0 & 0 & 485 & 248 & 0,89 & \\
\hline 21 & 2 & 0 & 0 & 437 & 211 & 0,9 & 0 \\
\hline 22 & & c & & 582 & 282 & 0,9 & \\
\hline 23 & 25 & 0 & 0 & 354 & 171 & 0,9 & \\
\hline 24 & 25 & & & 349 & 169 & 0,9 & \\
\hline 25 & 25 & 0 & 0 & 437 & 224 & 0,89 & 0 \\
\hline 26 & 25 & 0 & 0 & 582 & 282 & 0,9 & \\
\hline 27 & 2 & 0 & 0 & 24 & 223 & 0,92 & 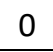 \\
\hline 28 & 25 & 0 & 0 & 592 & 287 & 0,9 & \\
\hline 29 & 20 & 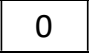 & 0 & 353 & 171 & 0,9 & 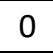 \\
\hline 30 & 25 & 0 & 0 & 31 & 323 & 0,89 & 0 \\
\hline 31 & 20 & 0 & 0 & 432 & 221 & 0,89 & 0 \\
\hline 32 & 21 & 0 & 0 & 82 & 14 & 0,88 & 0 \\
\hline 33 & 25 & 0 & 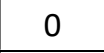 & 524 & 268 & 0,89 & 0 \\
\hline 34 & 25 & 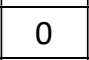 & 0 & 679 & 348 & 0,89 & 0 \\
\hline 35 & 25 & 0 & 0 & 582 & 314 & 0,88 & 0 \\
\hline 36 & 25 & 0 & 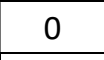 & 437 & 236 & 0,88 & 0 \\
\hline 37 & 25 & 0 & 0 & 518 & 265 & 0,89 & \\
\hline
\end{tabular}

B. Prosedur Pengolahan Data

Prosedur pengolahan data adalah dengan menggunakan ETAP yang dilakukan pada sistem jaringan 37 bus.

Urutan langkah-langkah dalam menganalisis aliran daya berdasarkan data-data yang ada adalah sebagai berikut :

1) Jalankan ETAP

2) Pilih menu file pada tampilan ETAP lalu pilih new project

3) Lalu akan terlihat tampilan create new project dan isi kolom pada "name" pada menu dan pastikan Unit System yang digunakan adalah "Metric", pilih "OK" jika data tersebut telah terisi.

4) Setelah itu akan terlihat menu "User Information", jika sudah terisi maka pilih tombol "OK" 
5) Lalu membuat one-line diagram pada lembar kerja ETAP 12.6.0

6) Setelah itu masukkan sumber ke dalam lembar kosong di monitor dengan cara mengklik icon sumber yang akan dipilih, pilih icon Power Grid:

7) Setelah itu masukkan sumber yang lainnya pilih Icon Bus

8) Setelah itu masukkan sumber yang lainnya, pilih icon Transmision Line.

9) Setelah itu masukkan sumber yang lainnya, pilih icon Trafo

10) Setelah itu masukkan nilai beban pada penyulang dengan cara klik pada icon Static Load maka akan muncul pilihan Loading, pada menu tersebut terdapat rating beban, persentase LWBP dan persentase WBP yang harus diisi sesuai data yang ada.

11) Selanjutnya apabila single line diagram tersebut sudah selesai, hasilnya bisa dilihat dengan mengklik Load Fload Analysis yang terdapat pada tampilan ETAP 12.6.0

12) Setelah itu kita mengklik Load Fload Analysis lalu kita harus menentukan metode yang akan kita gunakan dengan memilih options.

13) Setelah itu semua dilengkapi maka kita bisa melihat hasilnya dengan memilih Run Load Flow pada tampilan, kemudian akan keluar hasilnya

Selanjutnya kita pilih Display Options untuk memilih hasil analisis yang kita inginkan.

\section{HASIL DAN PEMBAHASAN}

\section{A. Hasil Simulasi}

Sistem tenaga listrik merupakan suatu sistem penyaluran energi listrik, dimana energi yang dihasilkan oleh pusat pembangkit tenaga listrik disalurkan ke beban pada tingkat tegangan yang di butuhkan, yaitu tegangan primer $(220 \mathrm{kV})$ dan tegangan sekunder (220/380 volt). Dalam kasus aliran daya bahwa beban dianggap dalam kondisi seimbang dan simulasi aliran daya akan dianalisis pada masing masing bus pada tiap saluran.

Analisis terhadap objek penelitian dilakukan dengan mengadakan pengujian serta melakukan entry data yang diambil dari sistem IEEE 37 bus, untuk menganalisisnya digunakan Electrical Transient Analysis Program 12.0 (ETAP). Perhitungan aliran daya ini dilakukan untuk mengetahui aliran daya, besarnya tegangan, daya aktif dan daya reaktif serta susut daya yang terjadi pada tiap saluran. Hasil siumlasi dari metode Fast Decoupled diperoleh setelah melakukan iterasi yang ke 2 dalam waktu \pm 2 detik.

Dari analisis dapat diperoleh daya aktif sebesar 17.146.000,000 Watt, daya reaktif sebesar 9.539 .000 Var. Total drop tegangan keseluruhan sistem yaitu sebesar $31.9 \%$, nilai susut daya yang diperoleh dari keseluruhan sistem, untuk daya aktif (P) yaitu sebesar 766.100 Watt, daya reaktif (Q) yaitu sebesar 3.557.200 Var. Bus yang digunakan untuk simulasi ini sebanyak 37 bus dan sumber daya (Power Grid) diamsusikan sebesar Mvasc, 220kV dengan Frekuensi $50 \mathrm{~Hz}$, jaringan yang digunakan yaitu sistem radial.

\section{B. Drop Tegangan}

Drop Tegangan pada standar IEEE sistem jaringan 37 bus dapat dilihat pada tabel dibawah ini.

Tabel 2. Drop Tegangan pada tiap saluran

\begin{tabular}{|c|c|c|c|c|}
\hline \multirow[t]{2}{*}{ No } & \multirow[t]{2}{*}{ Line } & \multirow[t]{2}{*}{ BUS } & Arus & \multirow[t]{2}{*}{$\mathrm{Vd}(\mathrm{V})$} \\
\hline & & & (A) & \\
\hline 1 & - & Bus 1 ke Bus 2 & 51,8 & \\
\hline 1 & Line 1 & Bus 2 ke Bus 3 & 461,7 & 2,22 \\
\hline 2 & Line 3 & Bus 3 ke Bus 4 & 94,8 & 0,57 \\
\hline 3 & Line 4 & Bus 4 ke Bus 5 & 91,6 & 0,54 \\
\hline 4 & Line 5 & Bus 5 ke Bus 6 & 8,0 & 0,03 \\
\hline 5 & Line 6 & Bus 6 ke Bus 7 & 5,6 & 0,02 \\
\hline 6 & Line 7 & Bus 5 ke Bus 8 & 79,5 & 0,68 \\
\hline 7 & Line 8 & Bus 8 ke Bus 9 & 23,1 & 0,02 \\
\hline 8 & Line 9 & Bus 9 ke Bus 10 & 10,0 & 0,01 \\
\hline 9 & Line 10 & Bus 8 ke Bus 11 & 46,8 & 0,18 \\
\hline 10 & Line 11 & Bus 11 ke Bus 12 & 12,7 & 0,01 \\
\hline 11 & Line 12 & Bus 11 ke Bus 13 & 19,5 & 0,01 \\
\hline 12 & Line 13 & Bus 3 ke Bus 14 & 36,7 & 0,05 \\
\hline 13 & Line 14 & Bus 14 ke Bus 15 & 17,1 & 0,03 \\
\hline 14 & Line 15 & Bus 14 ke Bus 16 & 9,8 & 0,03 \\
\hline 15 & Line 16 & Bus 3 ke Bus 17 & 326,3 & 0,74 \\
\hline 16 & Line 17 & Bus 17 ke Bus 18 & 54,0 & 0,38 \\
\hline 17 & Line 18 & Bus 18 ke Bus 19 & 44,3 & 0,38 \\
\hline 18 & Line 19 & Bus 19 ke Bus 20 & 13,9 & 0,09 \\
\hline 19 & Line 20 & Bus 19 ke Bus 21 & 16,6 & 0,1 \\
\hline 20 & Line 21 & Bus 17 ke Bus 22 & 246,5 & 1,46 \\
\hline 21 & Line 23 & Bus 22 ke Bus 23 & 229,8 & 0,84 \\
\hline 22 & Line 24 & Bus 23 ke Bus 24 & 10,1 & 0,03 \\
\hline 23 & Line 26 & Bus 23 ke Bus 25 & 12,8 & 0,07 \\
\hline 24 & Line 28 & Bus 23 ke Bus 26 & 196,6 & 1,23 \\
\hline
\end{tabular}


Arnawan Hasibuan ${ }^{1}$, Muzamir Isa ${ }^{1,2}$, Mohd Irwan Yusoff $^{2}$, Siti Rafidah Abdul Rahim²: ANALISA ALIRAN DAYA PADA SISTEM TENAGA LISTRIK DENGAN METODE FAST DECOUPLED MENGGUNAKAN SOFTWARE ETAP

\begin{tabular}{|l|c|c|c|c|}
\hline \multirow{2}{*}{ No } & \multirow{2}{*}{ Line } & BUS & Arus & \multirow{2}{*}{ Vd(V) } \\
\cline { 4 - 4 } & & & $(\mathrm{A})$ & \\
\hline 25 & Line 29 & Bus 26 ke Bus 27 & 179,5 & 0,66 \\
\hline 26 & Line 30 & Bus 27 ke Bus 28 & 164,4 & 1,15 \\
\hline 27 & Line 32 & Bus 28 ke Bus 29 & 146,6 & 0,49 \\
\hline 28 & Line 33 & Bus 29 ke Bus 30 & 50,6 & 0,29 \\
\hline 29 & Line 34 & Bus 30 ke Bus 31 & 13,2 & 0,12 \\
\hline 30 & Line 35 & Bus 30 ke Bus 32 & 18,1 & 0,13 \\
\hline 31 & Line 36 & Bus 29 ke Bus 33 & 85,3 & 0,47 \\
\hline 32 & Line 37 & Bus 33 ke Bus 34 & 69,2 & 0,74 \\
\hline 33 & Line 38 & Bus 34 ke Bus 35 & 48,2 & 0,39 \\
\hline 34 & Line 39 & Bus 35 ke Bus 36 & 13,8 & 0,08 \\
\hline 35 & Line 40 & Bus 35 ke Bus 37 & 16,1 & 0,07 \\
\hline
\end{tabular}

Persentase drop tegangan yang diizinkan untuk jaringan adalah $+5 \%$. Perhitungan drop tegangan secara simulasi dengan menggunakan ETAP, pada tegangan menengah $220 \mathrm{kV}$ (100\%), bus yang mengalami drop tegangan $\geq 5 \%$ (Nilai nyata $95 \%$ dari $220 \mathrm{kV}$ ) atau mengalami kelebihan tegangan (over voltage) sebesar $\geq 5 \%$ (nilai nyata $105 \%$ dari $220 \mathrm{kV}$ ) dianggap tidak aman bagi sistem.

Dari hasil simulasi yang di dapat pada Tabel 2 terlihat bahwa kondisi tegangan dari tiap-tiap bus mengalami penurunan, tetapi besarnya masih berada dalam batas yang telah ditentukan, yaitu sebesar $10 \%$ sampai $+5 \%$ dari nilai tegangan dasar dan dapat diketahui bahwa nilai tegangan yang paling rendah terjadi pada saluran 39 yaitu penghubung antara dari bus 35 ke bus 36 dan pada saluran 40 yaitu penghubung antara daari bus35 ke bus37 yaitu sebesar 20,782 Volt.

C. 4.4 Susut Daya (Losses)

Susut daya pada standar IEEE sistem jaringan 37 bus dapat dilihat pada tabel dibawah ini.

Tabel 3. Susut daya dari tiap saluran pada 37 bus

\begin{tabular}{|c|c|c|c|c|}
\hline No & Line & Dari - Ke & $\begin{array}{c}\text { Daya } \\
\text { Aktif } \\
(\mathrm{kW})\end{array}$ & $\begin{array}{c}\text { Daya } \\
\text { Reaktif } \\
(\mathrm{kVar})\end{array}$ \\
\hline 1 & - & Bus 1 ke Bus 2 & 116,6 & 2332,6 \\
\hline 1 & Line 1 & Bus 2 ke Bus 3 & 177,9 & 600,5 \\
\hline 2 & Line 3 & Bus 3 ke Bus 4 & 15,1 & 17,7 \\
\hline 3 & Line 4 & Bus 4 ke Bus 5 & 14,0 & 16,2 \\
\hline 4 & Line 5 & Bus 5 ke Bus 6 & 0,1 & $-2,6$ \\
\hline 5 & Line 6 & Bus 6 ke Bus 7 & 0,0 & $-2,5$ \\
\hline 6 & Line 7 & Bus 5 ke Bus 8 & 15,3 & 16,2 \\
\hline
\end{tabular}

\begin{tabular}{|c|c|c|c|c|}
\hline No & Line & Dari-Ke & $\begin{array}{l}\text { Daya } \\
\text { Aktif } \\
(\mathrm{kW})\end{array}$ & $\begin{array}{c}\text { Daya } \\
\text { Reaktif } \\
\text { (kVar) }\end{array}$ \\
\hline 7 & Line 8 & Bus 8 ke Bus 9 & 0,1 & $-0,4$ \\
\hline 8 & Line 9 & Bus 9 ke Bus 10 & 0,0 & $-1,0$ \\
\hline 9 & Line 10 & Bus 8 ke Bus 11 & 2,4 & 0,7 \\
\hline 10 & Line 11 & Bus 11 ke Bus 12 & 0,1 & $-0,7$ \\
\hline 11 & Line 12 & Bus 11 ke Bus 13 & 0,1 & $-0,4$ \\
\hline 12 & Line 13 & Bus 3 ke Bus 14 & 0,5 & $-0,2$ \\
\hline 13 & Line 14 & Bus 14 ke Bus 15 & 0,1 & $-0,9$ \\
\hline 14 & Line 15 & Bus 14 ke Bus 16 & 0,0 & $-2,1$ \\
\hline 15 & Line 16 & Bus 3 ke Bus 17 & 53,7 & 120,8 \\
\hline 16 & Line 17 & Bus 17 ke Bus 18 & 3,2 & 1,9 \\
\hline 17 & Line 18 & Bus 18 ke Bus 19 & 4,7 & 0,8 \\
\hline 18 & Line 19 & Bus 19 ke Bus 20 & 0,4 & $-4,1$ \\
\hline 19 & Line 20 & Bus 19 ke Bus 21 & 0,5 & $-3,7$ \\
\hline 20 & Line 21 & Bus 17 ke Bus 22 & 99,4 & 141,3 \\
\hline 21 & Line 23 & Bus 22 ke Bus 23 & 53,4 & 75,7 \\
\hline 22 & Line 24 & Bus 23 ke Bus 24 & 0,1 & $-2,2$ \\
\hline 23 & Line 26 & Bus 23 ke Bus 25 & 0,2 & $-3,2$ \\
\hline 24 & Line 28 & Bus 23 ke Bus 26 & 67,0 & 93,8 \\
\hline 25 & Line 29 & Bus 26 ke Bus 27 & 32,6 & 45,3 \\
\hline 26 & Line 30 & Bus 27 ke Bus 28 & 52,4 & 72,2 \\
\hline 27 & Line 32 & Bus 28 ke Bus 29 & 20,0 & 27,1 \\
\hline 28 & Line 33 & Bus 29 ke Bus 30 & 4,1 & 2,4 \\
\hline 29 & Line 34 & Bus 30 ke Bus 31 & 0,5 & $-5,2$ \\
\hline 30 & Line 35 & Bus 30 ke Bus 32 & 0,6 & $-3,4$ \\
\hline 31 & Line 36 & Bus 29 ke Bus 33 & 11,1 & 12,8 \\
\hline 32 & Line 37 & Bus 33 ke Bus 34 & 14,1 & 14,1 \\
\hline 33 & Line 38 & Bus 34 ke Bus 35 & 5,2 & 2,8 \\
\hline 34 & Line 39 & Bus 35 ke Bus 36 & 0,3 & $-2,9$ \\
\hline 35 & Line 40 & Bus 35 ke us 37 & 0,3 & $-2,2$ \\
\hline \multicolumn{3}{|c|}{ Total } & 766,1 & 3557,2 \\
\hline
\end{tabular}

Dari Tabel 3 diketahui bahwa besarnya susut daya pada masing-masing saluran. Susut daya yang paling terbesar terjadi pada saluran 1 yaitu penghubung antara bus 2 ke bus 3sebesar 177.9 KWatt pada daya aktif, pada daya reaktifnya susut daya yang paling terbesar juga terjadi pada penghubung dari bus1 ke bus2 yaitu sebesar 2332,6 Kvar. Susut daya yang paling kecil pada daya aktif (P) terjadi pada saluran 5, saluran 8, saluran 11, saluran 12 , saluran 14 , saluran 15 dan saluran 24 yaitu sebesar $0.1 \mathrm{Kwatt}$. Pada daya reaktif susut daya yang paling kecil terjadi pada saluran 29 yaitu sebesar -5.2 Kvar. Tetapi hanya satu saluran yang tidak mengalami susut daya yaitu saluran 9 sedangkan 
susut daya total pada saluran adalah 766.1 Kwatt daya aktif (P) dan 3557.2 Kvar daya reaktif(Q).

Analisis Perbandingan

Analisis perbandingan ini dilakukan pada setiap saluran untuk mengetahui selisih antara hasil yang diperoleh secara perhitungan dangan menggunakan software etap, seperti pada Tabel 4.

Tabel 4. Hasil Perbandingan Aliran Daya Pada Tiap Saluran

\begin{tabular}{|c|c|c|c|c|}
\hline & \multicolumn{2}{|c|}{ Perhitungan } & \multicolumn{2}{|c|}{ Software Etap } \\
\hline & P(Watt) & $O(V$ & P(Watt) & Q ( \\
\hline 3 & 2889 & 2167 & 3365000,000 & 165 \\
\hline 4 & 279 & 2094 & 3234000,000 & $157^{\circ}$ \\
\hline 5 & 27,537 & 1829 & 281000,000 & 136000,000 \\
\hline 6 & 1707109,276 & 1280 & 194000,000 &, 000 \\
\hline 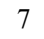 & 2423 & 1817 & 2793000,000 & 1355 \\
\hline$\gamma$ & 7041 & 528 & 805000,000 & 3890 \\
\hline 9 & 304 & 228 & 0,000 & 16 \\
\hline 10 & 14266556,090 & 1069 & 1632000,000 & 7870 \\
\hline 11 & 3871479,965 & 2903 & 437000,000 & 2230 \\
\hline 12 & 594 & 445 & 679 & 329 \\
\hline 13 & 1118 & 839 & 00,000 &, 000 \\
\hline 14 & 5212780,110 & 3909 & 601000,000 & 307000,000 \\
\hline 15 & 2987 & 2240 & 349000,000 & 1670 \\
\hline 16 & 99469599,420 & 7460 & 113 &, 000 \\
\hline 17 & 1646141 & 12346 & 1910000,000 & 9190 \\
\hline 18 & 1350 & 1012 & 155 & 7580 \\
\hline 19 & 423 & 317 & 485 & 244 \\
\hline 20 & 5060 & 379 & 0,000 & 278 \\
\hline 21 & 7514 & 5635 & 8519000,000 & 456 \\
\hline 23 & 7005244 & 5253 & 7838000,000 & 4143 \\
\hline 24 & 3078 & 230 & 00,000 & 0,000 \\
\hline 26 & 390 & 292 & 00,000 & 221 \\
\hline 2 & 5993 & 4494 & 00,000 & 350 \\
\hline 29 & 54718 & 4103 & 599 & 313 \\
\hline 30 & 50115850 & 37580 & 5439000,000 & 2865 \\
\hline 32 & 4468968 & $3351^{\prime}$ & 4794000,000 & 2506000,00 \\
\hline 33 & 154249 & 115687 & 1650000,000 & 852000,000 \\
\hline 34 & 402 & 3017 & 432000,000 & 216000,00 \\
\hline 35 & 21,053 & 4138 & 583000,000 & 311000,000 \\
\hline 3 & 2600 & 19502 & 2771000,000 & 1456 \\
\hline 37 & 2109 & 15821 & 2236000,000 & 1175000,000 \\
\hline 38 & 14693333,410 & 11020000,060 & 1543000,000 & 813000,000 \\
\hline 39 & 4206805,001 & 3155 & 437000,000 & 233000,000 \\
\hline 40 & 4907939,168 & 3680954,376 & 518000,000 & 263000,000 \\
\hline
\end{tabular}

Tabel 5. Hasil Perbandingan Losses

\begin{tabular}{|c|c|c|c|c|}
\hline \multirow{2}{*}{ Line } & \multicolumn{2}{|c|}{ Perhitungan } & \multicolumn{2}{c|}{ Software Etap } \\
\cline { 2 - 5 } & P(Watt) & Q (Var) & P(Watt) & Q (Var) \\
\hline 3 & 4702,055 & 7187,924 & 15100,000 & 17700,000 \\
\hline 4 & 4353,694 & 6655,392 & 14000,000 & 16200,000 \\
\hline 5 & 20,755 & 31,728 & 100,000 & $-2600,000$ \\
\hline 6 & 9,831 & 15,028 & 0,000 & $-2500,000$ \\
\hline 7 & 4755,204 & 7269,172 & 15300,000 & 16200,000 \\
\hline 8 & 41,532 & 63,489 & 100,000 & $-400,000$ \\
\hline 9 & 12,972 & 19,830 & 0,000 & $-1000,000$ \\
\hline 10 & 748,177 & 1143,721 & 2400,000 & 700,000 \\
\hline 11 & 15,692 & 23,988 & 100,000 & $-700,000$ \\
\hline 12 & 24,663 & 37,702 & 100,000 & $-400,000$ \\
\hline 13 & 145,599 & 222,574 & 500,000 & $-200,000$ \\
\hline 14 & 38,564 & 58,951 & 100,000 & $-900,000$ \\
\hline 15 & 24,917 & 38,089 & 0,694 & $-2100,000$ \\
\hline 16 & 17171,754 & 40348,512 & 53700,000 & 120800,000 \\
\hline 17 & 1008,703 & 1541,981 & 3200,000 & 1900,000 \\
\hline 18 & 1463,802 & 2237,680 & 4700,000 & 800,000 \\
\hline 19 & 109,025 & 166,664 & 400,000 & $-4100,000$ \\
\hline 20 & 147,749 & 225,860 & 500,000 & $-3700,000$ \\
\hline 21 & 31002,844 & 47393,340 & 99400,000 & 141300,000 \\
\hline 23 & 16668,963 & 25481,464 & 53400,000 & 75700,000 \\
\hline 24 & 29,774 & 45,514 & 100,000 & $-2200,000$ \\
\hline 26 & 74,387 & 113,713 & 200,000 & $-3200,000$ \\
\hline 28 & 20891,168 & 31935,851 & 67000,000 & 93800,000 \\
\hline 29 & 10170,386 & 15547,237 & 32600,000 & 45300,000 \\
\hline 30 & 16945,614 & 25904,373 & 52400,000 & 72200,000 \\
\hline 32 & 6226,277 & 9517,967 & 20000,000 & 27100,000 \\
\hline 33 & 1284,236 & 1963,182 & 4100,000 & 2400,000 \\
\hline 34 & 140,135 & 214,221 & 500,000 & $-5200,000$ \\
\hline 35 & 196,905 & 301,005 & 600,000 & $-3400,000$ \\
\hline 36 & 3460,799 & 5290,445 & 11100,000 & 12800,000 \\
\hline 37 & 4493,219 & 6868,682 & 14100,000 & 14100,000 \\
\hline 38 & 1627,402 & 2487,772 & 5200,000 & 2800,000 \\
\hline 39 & 92,228 & 140,987 & 300,000 & $-2900,000$ \\
\hline 40 & 67,249 & 102,803 & 300,000 & $-2200,000$ \\
\hline
\end{tabular}

Pada Tabel 5 dapat dilihat bahwa selisih nilai aliran daya dari hasil perhitungan menggunakan software etap dengan perhitungan manual nilainya jauh berbeda seperti pada 
saluran 29 yaitu nilai daya aktif $(\mathrm{P})$ sebesar 5.465.902.949,110 Watt atau 5.465.902,9491 $\mathrm{KW}$, daya reaktif (Q) pada line 16 sebesar 68.554.199,560 Watt atau 68.554,199560 KW. Nilai selisih terkecil daya aktif terdapat pada line 6 yaitu sebesar 1.513.109,276 Watt atau $1513,109276 \mathrm{KW}$, dan nilai reaktifnya yaitu 1.184.331,957 Watt atau 1.184,331957 KW.

Pada Table 5 juga dapat dilihat, hasil yang didapatkan dari antara hasil perhitungan mengunakan sofware dengan hasil perhitungan secara manual selisih nilainya jauh berbeda seperti pada line 21 nilai daya aktif (P) sebesar $68397 \mathrm{~W}$ atau $68,397 \mathrm{KW}$ dan nilai reaktif (Q) sebesar 93906,660 Watt atau 93,906660 KW. Nilai selisih losses yang paling kecil daya aktif (P) pada line 15 sebesar $24,222 \mathrm{~W}$ atau 0,24 KW, dan nilai reaktif(Q) pada line 19 yaitu sebesar 4266,664 Watt atau 4,266664 KW.

\section{KESIMPULAN}

Dari analisis dapat diperoleh daya aktif sebesar 17.146.000,000 Watt, daya reaktif sebesar 9.539.000 Var. Presentase drop tegangan total keseluruhan Pada 37 bus sistem standar IEEE yaitu sebesar $31.9 \%$. Susut daya terbesar terdapat pada saluran 1 yaitu 177,9 Kwatt dan 600,5 Mvar sedangkan losses terkecil terdapat pada saluran 5 penghubung antara bus 5 ke bus 6 yaitu $0.1 \mathrm{Kwatt}$ dan susut daya reaktif terkecil terdapat pada saluran 29 yaitu $-5,2$ Mvar.

Hasil simulasi pada software Etap dengan hasil perhitungan terjadi selisih yang besar seperti pada saluran 29 yaitu nilai daya aktif (P) sebesar 5.465.902.949,110 Watt atau 5.465.902,9491 KW, daya reaktif (Q) pada line 16 sebesar 68.554.199,560 Watt atau 68.554,199560 KW.

\section{DAFTAR PUSTAKA}

[1]. D. Sulistiyono, J. WINDARTO, and K. Karnoto, "Perbandingan Metode Gauss-Seidel, Metode Newton Raphson Dan Metode Fast Decoupled Dalam Solusi Aliran Daya," Jurusan Teknik Elektro Fakultas Teknik Undip, 2011.

[2]. Supriyadi, "Analisa Aliran Daya pada Sistem Tenaga Listrik Menggunakan Software Etap 12.6," vol. 06 , no. 3 , p. 10.

[3]. G. P. ARITONANG, "STUDI ALIRAN DAYA PADA SISTEM TENAGA LISTRIK MENGGUNAKAN SOFTWARE ETAP 12.6. 0 DI PT CEMINDO GEMILANG SITE BAYAH," Universitas Mercu Buana Jakarta, 2018.

[4]. J. J. Grainger, "William d. Stevenson, JR.,“,” Power Syst. Anal. McGraw-Hill, Inc, 1994.

[5]. S. Rudi Salman, Mustamam, "Simulasi dan Analisis Aliran Daya Sistem Tenaga Listrik Menggunakan Perangkat Lunak Electrical Transient Analyser Program (ETAP) Versi 4.0.”

[6]. K. Rusdi, "Studi Aliran Daya Listrik Di Pt Showa Indonesia Manufacturing," 2016.

[7]. R. W. Novialifiah, A. Soeprijanto, and R. S. Wibowo, "Algoritma Aliran Daya untuk Sistem Distribusi Radial dengan Beban Sensitif Tegangan," J. Tek. ITS, vol. 3, no. 1, pp. B7-B11, 2014.

[8]. Winardi, A. Warsito, and M. R. Kartika, "Analisa Perbaikan Susut Teknis dan Susut Tegangan Pada Penyulang KLS 06 di GI Kalisari dengan menggunakan Software Etap 7.5. 0," Transmisi, vol. 17, no. 3, pp. 135-140, 2015.

[9]. O. Candra, "PENERAPAN METODA DECOUPLED BERBASIS ALIRAN DAYA OPTIMAL PADA SISTEM TENAGA.” 